\title{
Neonatal Graves' Disease and Cholestatic Jaundice: Case Series and Review of the Literature
}

\author{
Osama Almadhoun ${ }^{1 *}$, Teresa Rivera-Penera ${ }^{2}$, Lauren Lipeski ${ }^{3}$ \\ ${ }^{1}$ University of Kansas Medical Center, Kansas City, USA \\ ${ }^{2}$ Division of Pediatric Gastroenterology, St. Joseph's Children Hospital, Paterson, USA \\ ${ }^{3}$ Division of Pediatric Endocrinology, Upstate Medical Center, Golisano Children Hospital, Syracuse, USA \\ Email: oalmadhoun@KUMC.edu, lipeskil@upstate.edu
}

Received 11 April 2015; accepted 26 June 2015; published 29 June 2015

Copyright (C) 2015 by authors and Scientific Research Publishing Inc.

This work is licensed under the Creative Commons Attribution International License (CC BY). http://creativecommons.org/licenses/by/4.0/

(c) (i) Open Access

\begin{abstract}
Cholestatic jaundice and elevated liver enzymes are uncommon, but recognized, manifestations of neonatal thyrotoxicosis. Current guidelines for evaluation of cholestatic jaundice and reviews in Neonatology literature do not discuss hyperthyroidism in the differential diagnosis of cholestatic jaundice. We report two cases of neonatal thyrotoxicosis secondary to neonatal Graves' disease that presented with cholestatic jaundice and elevated liver enzymes at birth. Early recognition of thyrotoxicosis as a cause of the hepatic disease in the neonate is crucial to prevent unnecessary diagnostic procedures and to initiate timely treatment.
\end{abstract}

\section{Keywords}

Neonate, Graves' Disease, Thyrotoxicosis, Hyperthyroidism, Cholestasis, Hepatitis, Jaundice, Conjugated Hyperbilirubinemia

\section{Introduction}

Cholestatic jaundice and elevated liver enzymes are uncommon, but recognized, manifestations of neonatal thyrotoxicosis. We report two neonates with cholestasis associated with neonatal thyrotoxicosis caused by maternal Graves' disease. The cause of liver disease in neonatal thyrotoxicosis has not been clearly established. Early recognition of thyrotoxicosis as a cause of the hepatic disease in the neonate is crucial to prevent unnecessary diagnostic procedures and to initiate timely treatment.

${ }^{*}$ Corresponding author.

How to cite this paper: Almadhoun, O., Rivera-Penera, T. and Lipeski, L. (2015) Neonatal Graves' Disease and Cholestatic Jaundice: Case Series and Review of the Literature. Open Journal of Pediatrics, 5, 179-184.

http://dx.doi.org/10.4236/ojped.2015.52027 


\section{Case 1}

A $1285 \mathrm{~g}$ (50\% percentile) female infant born by cesarean section at 29 weeks gestation to a 36-year-old mother, gravida 2 para 1, due to premature labor. The mother had a history of hypothyroidism and was treated with thyroid hormone replacement throughout the pregnancy.

Vital signs were within normal at birth except for tachypnea with a respiratory rate of $60-70$ /minute. The infant had respiratory distress secondary to hyaline membrane disease which required surfactant therapy and ventilator support for four days. Initial exam revealed jaundice and a diffuse rash with petichiae and macules distributed over the entire body but sparing palms and soles. Hepatosplenomegaly was present (liver $3.5 \mathrm{~cm}$ below costal margin, spleen $4 \mathrm{~cm}$ below costal margin). Facies were triangular with frontal bossing and both eyes were prominent with yellow sclera. A II/VI systolic murmur was noted.

Laboratory studies on the first day of life revealed thrombocytopenia with platelet count of 64,000/L, conjugated hyperbilirubinemia with a total bilirubin of $10.7 \mathrm{mg} / \mathrm{dl}$ and a direct of $7.8 \mathrm{mg} / \mathrm{dl}$, and elevated liver enzymes with AST of $586 \mathrm{U} / \mathrm{L}(18$ - 74), and ALT of $177 \mathrm{U} / \mathrm{L}$ (8 - 36). Based on the clinical picture, congenital infection was suspected and studies for toxoplasma, rubella, cytomegalovirus and herpes (TORCH) were performed and were normal. On day 2 of life, an echocardiogram revealed significant pulmonary hypertension with bidirectional shunt through a patent ductus arteriosus. Cranial ultrasound showed borderline enlargement of the lateral ventricles with no intracranial calcification or bleeding.

On day 4, the infant was extubated to CPAP but remained tachycardic with a heart rate of $180-200 /$ minute and worsening of tachypnea with respiratory rate of 70 - 80/minute was noted. Nitric oxide (NO) was started for persistent pulmonary hypertension. NO was continued for 3 days and the pulmonary blood pressure normalized thereafter. Thrombocytopenia persisted and the conjugated hyperbilirubinemia continued to increase to a peak of $20.3 \mathrm{mg} / \mathrm{dl}$ total and $11.5 \mathrm{mg} / \mathrm{dl}$ conjugated on day 8 of life. Liver enzymes remained elevated and peaked on day 11 with AST of $771 \mathrm{U} / \mathrm{L}$ and ALT of $364 \mathrm{U} / \mathrm{L}$. Abdominal ultrasound confirmed hepatosplenomegaly without a discrete mass lesion and no intrahepatic or extrahepatic biliary tree obstruction. Studies to evaluate the etiology of cholestatic jaundice including alpha-1-antitrypsin deficiency, tyrosinemia, and galactosemia were performed and were normal.

On day 11, mild exophthalmos of the mother was noted and further questioning revealed that she was diagnosed with Graves' disease 8 years previously and treated with radioactive iodine therapy resulting in hypothyroidism. Based on this history thyroid profile was obtained on the infant and revealed elevated T4 at $25.3 \mathrm{ug} / \mathrm{dl}$ (normal range 9.8 - 16.6) and suppressed TSH $0.011 \mathrm{uIU} / \mathrm{ml}$ (normal range 0.4 - 8.6). Antibody mediated Neonatal Grave' disease was confirmed by presence of TSH receptor antibodies which were significantly elevated at $302 \%$ (normal $0 \%-129 \%$ ). Careful examination of the infant revealed diffuse goiter. Treatment was initiated with methimazole on day 12 and resulted in gradual improvement of the thyroid profile as well as the conjugated bilirubinemia and liver function tests (Table 1). Treatment with methimazole continued for 2 months. A slight increase in AST and ALT was noted one month after Methimazole discontinuation but then gradually improved thereafter.

\section{Case 2}

An 1820 gm ( $75^{\text {th }}$ percentile) male infant born by cesarean section at 32 weeks gestation to a 35-year-old mother, gravida 2 para 1, with a history of hypothyroidism treated with thyroid hormone replacement therapy.

Initial physical exam was remarkable for triangular facies, penoscrotal hypospadias, hepatosplenomegaly and jaundice. Vital signs were significant for tachypnea at birth with a respiratory rate of 50 - 60/minute. The baby required ventilatory support for 6 days by CPAP.

Laboratory studies on the first day of life revealed thrombocytopenia with platelets of 75,000/L, conjugated hyperbilirubinemia with a total bilirubin of $8.3 \mathrm{mg} / \mathrm{dl}$ and a direct bilirubin of $4.4 \mathrm{mg} / \mathrm{dl}$. On day 2, elevated liver enzymes were noted with ALT of $67 \mathrm{U} / \mathrm{L}$ and AST of $116 \mathrm{U} / \mathrm{L}$. Cranial ultrasound showed mild lateral ventricular enlargement with no calcification or bleeding. Echocardiogram revealed mild pulmonary hypertension with tricuspid regurgitation and increased right ventricular pressure. Evaluation for congenital infection (toxoplasma, rubella, syphilis, CMV, and HSV), viral hepatitis, alpha-1-antitrypsin deficiency and tyrosinemia were normal.

Endocrinology evaluation was performed to evaluate the pituitary function as part of the diagnostic workup for penoscrotal hypospadias revealed neonatal hyperthyroidism. On day 6 of life, Total T3 was 688 ng/dl (normal range 0 - 256), free T4 > $12 \mathrm{ng} / \mathrm{dl}$ (normal range 1.71 - 6.6), total T4 $28 \mathrm{ug} / \mathrm{dl}$ (normal range 10.1 - 20) and TSH was suppressed $0.006 \mathrm{uIU} / \mathrm{ml}$ (normal range 0.4 - 8.6). Antibody mediated neonatal Graves' disease was 
confirmed by presence of elevated TSH receptor antibodies at $49 \%$ (normal $0 \%-14 \%$ ). Additional history elicited after identification of neonatal Graves’ disease revealed maternal history of Gravess’ disease treated with radioactive iodine 5 years prior to this pregnancy with resultant hypothyroidism. The infant was started on propylthiouracil (PTU) and propanolol.

Thyroid profile improved within $48 \mathrm{hrs}$ to T3 of $371 \mathrm{ng} / \mathrm{dl}$, free T4 of $5.58 \mathrm{ng} / \mathrm{dl}$, and total T4 of $22.3 \mathrm{ug} / \mathrm{dl}$. Thyroid hormone levels normalized by 3 weeks of age (Table 2). The conjugated hyperbilirubinemia peaked on day 12 of life with a total bilirubin of $10.2 \mathrm{mg} / \mathrm{dl}$ and a direct of $6.2 \mathrm{mg} / \mathrm{dl}$ and gradually improved with normalization by 8 weeks. Liver enzymes transiently increased after initiation of PTU treatment and peaked on day 12 of life (6 days on PTU treatment) with ALT $137 \mathrm{U} / \mathrm{L}$ and AST $230 \mathrm{U} / \mathrm{L}$. Thereafter, there was gradual improvement in the ALT and AST with normalization by 8 months (Table 2).

\section{Table 1. Case 1 laboratory studies.}

\begin{tabular}{|c|c|c|c|c|c|c|c|}
\hline $\begin{array}{l}\text { Day of } \\
\text { Life }\end{array}$ & $\begin{array}{l}\text { AST } \\
\text { (U/L) }\end{array}$ & $\begin{array}{l}\text { ALT } \\
(\mathrm{U} / \mathrm{L})\end{array}$ & $\begin{array}{l}\text { Bilirubin Total } \\
\text { (mg/dl) }\end{array}$ & $\begin{array}{l}\text { Bilirubin Direct } \\
\text { (mg/dl) }\end{array}$ & Platelet $\times 10^{3} / \mathrm{ul}$ & Total T4 (ug/dl) & TSH (uIU/ml) \\
\hline 1 & 586 & 177 & 10.7 & 7.8 & 64 & - & - \\
\hline 3 & 342 & 197 & 15.9 & 9.8 & 98 & - & - \\
\hline 8 & 405 & 234 & 20.7 & 12.1 & 84 & - & - \\
\hline 11 & 771 & 364 & 15.4 & 9.0 & 60 & 25.3 & 0.011 \\
\hline 20 & 430 & 199 & 10.6 & 6.3 & 76 & 13.1 & 0.014 \\
\hline 30 & 369 & 237 & 9.4 & 5.8 & 169 & 9.9 & 0.012 \\
\hline 40 & 220 & 145 & 5.8 & 3.7 & 187 & 3.7 & 0.012 \\
\hline 60 & 301 & 273 & - & - & - & 7.6 & 0.223 \\
\hline 120 & 195 & 299 & 2.0 & 1.3 & - & 9.7 & 0.89 \\
\hline 200 & 89 & 145 & 0.3 & 0.12 & - & 6.4 & 0.59 \\
\hline 230 & 71 & 138 & 0.3 & 0.08 & - & - & - \\
\hline \multirow[t]{3}{*}{ Normal } & $(18-74)$ & $(8-36)$ & $0-3 d(2-10)$ & $0-3 d<1.5$ & $(250-450)$ & $1-7 \mathrm{~d}(10.1-20)$ & $(0.4-8.6)$ \\
\hline & & & $>1$ mo $(0-1.5)$ & $>1 \mathrm{mo}<0.5$ & & $8-14$ d (9.8 - 16.6) & \\
\hline & & & & & & $1 \mathrm{mo}-1 \mathrm{y}(5.5-16)$ & \\
\hline
\end{tabular}

AST: Aspartate Amino-Transferase; ALT: Alanine Amino-Transferase, T4: Thyroxine; TSH: Thyroid Stimulating Hormone.

Table 2. Case 2 laboratory studies.

\begin{tabular}{|c|c|c|c|c|c|c|c|}
\hline $\begin{array}{l}\text { Day of } \\
\text { Life }\end{array}$ & $\begin{array}{l}\text { AST } \\
\text { (U/L) }\end{array}$ & $\begin{array}{l}\text { ALT } \\
\text { (U/L) }\end{array}$ & $\begin{array}{c}\text { Bilirubin } \\
\text { Total (mg/dl) }\end{array}$ & $\begin{array}{c}\text { Bilirubin } \\
\text { Direct (mg/dl) }\end{array}$ & $\begin{array}{l}\text { Platelet } \\
\times 10^{3} / \mathrm{ul}\end{array}$ & $\begin{array}{l}\text { Total T4 } \\
\text { (ug/dl) }\end{array}$ & $\begin{array}{c}\text { TSH } \\
\text { (uIU/ml) }\end{array}$ \\
\hline $1-2$ & 116 & 67 & 8.3 & 4.1 & 75 & - & - \\
\hline 6 & 105 & 74 & 8.5 & 5.6 & 136 & 28 & 0.006 \\
\hline 12 & 230 & 137 & 10.2 & 6.2 & 302 & 20 & 0.007 \\
\hline 20 & 132 & 85 & 6.9 & 4.6 & 318 & 11 & 0.004 \\
\hline 30 & 121 & 119 & 7.0 & 4.7 & 297 & 9.9 & 0.010 \\
\hline 60 & 75 & 105 & 1.0 & 0.4 & - & - & 0.014 \\
\hline 120 & 60 & 75 & 0.6 & - & 265 & 10.8 & 0.275 \\
\hline 240 & 57 & 22 & - & - & 323 & 8.6 & 0.413 \\
\hline \multirow[t]{3}{*}{$\begin{array}{c}\text { Normal } \\
(18-74)\end{array}$} & $(18-74)$ & $(8-36)$ & $0-3 d(2-10)$ & $0-3 \mathrm{~d}<1.5$ & $(250-450)$ & $1-7 \mathrm{~d}(10.1-20)$ & $(0.4-8.6)$ \\
\hline & & & $>1 \mathrm{mo}(0-1.5)$ & $>1 \mathrm{mo}<0.5$ & & $8-14$ d (9.8 - 16.6) & \\
\hline & & & & & & $1 \mathrm{mo}-1$ y $(5.5-16)$ & \\
\hline
\end{tabular}




\section{Discussion}

Neonatal Grave' disease affects 1\% - 2\% of infants born to mothers with a history of Graves' disease [1] [2]. The disease results from the transplacental passage of maternal Thyroid Stimulating Hormone Receptor Antibodies (TSHR-AB) [2]-[4]. While most infants are born to women with active Graves' hyperthyroidism, the disorder can also occur in infants of women with a history of Graves’ hyperthyroidism treated with thyroidectomy or radioactive iodine in the past [5]. Our cases emphasize the importance of a thorough history in mothers who are on thyroid hormone replacement therapy during pregnancy to elucidate the etiology of the hypothyroidism. Recognition of the infants risk for neonatal Graves’ is crucial for early diagnosis and treatment. Measurement of maternal serum TSHR-Ab is also helpful in predicting whether a newborn will be affected [6].

Neonatal Graves' disease has been reported to cause low birth weight for gestational age, premature birth, microcephaly, frontal bossing and triangular facies, warm, moist skin, irritability and hyperactivity [7] [8]. Tachycardia with a bounding pulse, pulmonary hypertension, high-output heart failure, fetal hydrops, hyperphagia, poor weight gain and diarrhea may also be present [8]. Thrombocytopenia, hepatosplenomegaly, jaundice, diffuse goiter, stare and occasionally exophthalmos may be evident [9]. Untreated neonatal hyperthyroidism has a high mortality rate and serious neurologic sequelae [10].

The time of onset is variable, depending upon whether the mother is receiving an antithyroid drug at the time of delivery and the presence of TSH receptor blocking antibodies. Infants of mothers taking an antithyroid drug may be euthyroid at birth, and become hyperthyroid several days later, as the antithyroid drug is metabolized or excreted [11]. The presence of blocking antibodies may delay the onset of clinical hyperthyroidism by weeks or months. The symptoms usually resolve spontaneously by 3 to 12 weeks as the maternal TSHR-Ab disappears from the infant's circulation. By 4 months of age, most infant are euthyroid and off antithyroid medication treatment [8] [9].

Hepatic manifestations of Graves’ disease are recognized in both adults and neonates [12] [13]. The pathology of liver disease associated with hyperthyroidism was first reported in adults in the 1930s [13]. In a 1992 review of adults with hyperthyroidism in the Journal of Clinical Gastroenterology, the subset of patients without congestive heart failure presented with hepatosplenomegaly in $1 / 3$ and cholestatic jaundice in $1 / 2$ of the patients [13]. Two thirds of the patients had elevated liver enzymes, but only $5 \%$ of these had liver enzymes over 250 $\mathrm{U} / \mathrm{L}$.

Our two patients with neonatal hyperthyroidism presented with hepatosplenomegaly, conjugated hyperbilirubinemia and elevated liver enzymes. Hepatic manifestations of neonatal hyperthyroidism were reported as early as 1955 and are recognized, though less common, manifestations of neonatal Graves' disease [14]. Literature review identified 11 case reports discussing the hepatic manifestations of neonatal Graves’ disease [14]-[24]. The majority had hepatosplenomegaly and early cholestatic jaundice presenting at birth or in the first week of life. Approximately half reported elevated liver enzymes with AST generally higher than ALT as was evident in our patients. The highest levels reported were AST 1111 U/L [24] and ALT 465 U/L [17]. Very limited information is available about the time course of recovery. In our patients, the time course to complete recovery was 6 - 9 months with the improvement in AST and ALT lagging behind resolution of conjugated hyperbilirubinemia.

Conjugated hyperbilirubinemia is estimated to occur in 1 of 2500 live birth [25]. The differential diagnosis of conjugated hyperbilirubinemia is extensive, but most affected infants present with progressive and prolonged jaundice. The early cholestasis seen in our patients was also evident in the cases reported in the literature and may also be seen in patients with congenital infection and embryonic biliary atresia. Despite the recognition of the hepatic manifestations of hyperthyroidism in the literature, this complication of neonatal Graves' disease is not listed in the differential diagnosis of cholestatic jaundice in recent guidelines for evaluation of cholestatic jaundice [25]-[27]. This lack of recognition may result in a delay in diagnosis and appropriate therapy or lead to unnecessary diagnostic procedures.

The cause of liver disease in neonatal thyrotoxicosis has not been clearly established but several possibilities have been suggested. The hypermetabolic state may result in increase hepatic oxygen consumption without increased hepatic blood flow, leading to hepatic dysfunction [28] [29]. Another possibility is that thyrotoxicosis causes high output congestive heart failure (CHF), which may result in hepatic dysfunction and hepatosplenomegaly [30]. However, in both the adult and pediatric literature, the hepatic manifestations occur in hyperthyroid patients without CHF [13]. Propylthiouracil (PTU) induced hepatitis is another possible mechanism [30] [31]. In three reported cases the fetus was exposed to PTU, however, these infants had a mild elevation in liver en- 
zymes compared to the elevation reported in unexposed cases, including our two patients who were not exposed to PTU. Enlargement of the reticuloendothelial system seen in neonatal Graves' disease may disrupt hepatic architecture and cause cholestasis [32].

\section{Conclusion}

In summary, neonatal Graves’ disease is a rare, but potentially fatal, condition. Cholestatic jaundice with hepatosplenomegaly and hepatitis are unusual, but recognized, complications of neonatal Graves’ disease. Identification of an affected infant requires a careful maternal history, a high index of suspicion and an improved recognition of neonatal Graves’ disease in the differential diagnosis of cholestasis.

\section{Conflict of Interest}

The authors of this manuscript report no conflicts of interest including, but not limited to, consulting fees, paid expert testimony, employment, grants, honoraria, patents, royalties, stocks, or other financial or material gain that may involve the subject matter of the manuscript.

\section{References}

[1] Ramsay, I., Kaur, S. and Krassas, G. (1983) Thyrotoxicosis in Pregnancy: Results of Treatment by Antithyroid Drugs Combined with T4. Clinical Endocrinology (Oxford), 18, 73-85. http://dx.doi.org/10.1111/j.1365-2265.1983.tb03188.x

[2] McKenzie, J.M. and Zakarija, M. (1992) Fetal and Neonatal Hyperthyroidism and Hypothyroidism Due to Maternal TSH Receptor Antibodies. Thyroid, 2, 155-159. http://dx.doi.org/10.1089/thy.1992.2.155

[3] Sunshine, P., Kusumoto, H. and Kriss, J.P. (1965) Survival Time of Circulating Long-Acting Thyroid Stimulator in Neonatal Thyrotoxicosis: Implications for Diagnosis and Therapy of the Disorder. Pediatrics, 36, 869-876.

[4] Smallridge, R.C., Wartofsky, L., Chopra, I.J., Marinelli, P.V., Broughton, R.E., Dimond, R.C., et al. (1978) Neonatal Thyrotoxicosis: Alterations in Serum Concentrations of LATS-Protector, T4, T3, Reverse T3, and 3, 3'T2. Journal of Pediatrics, 93, 118-120. http://dx.doi.org/10.1016/S0022-3476(78)80620-9

[5] Volpé, R., Ehrlich, R., Steiner, G. and Row, V.V. (1984) Graves’ Disease in Pregnancy Years after Hyperthyroidism with Recurrent Passive-Transfer Neonatal Graves’ Disease in Offspring. Therapeutic Considerations. American Journal of Medicine, 77, 572-578. http://dx.doi.org/10.1016/0002-9343(84)90125-6

[6] Peleg, D., Cada, S., Peleg, A. and Ben-Ami, M. (2002) The Relationship between Maternal Serum Thyroid-Stimulating Immunoglobulin and Fetal and Neonatal Thyrotoxicosis. Obstetrics Gynecology, 99, 1040-1043. http://dx.doi.org/10.1016/S0029-7844(02)01961-0

[7] Farrehi, C. (1968) Accelerated Maturity in Fetal Thyrotoxicosis. Clinical Pediatrics, 7, 134-137. http://dx.doi.org/10.1177/000992286800700304

[8] Radetti, G., Zavallone, A., Gentili, L., Beck-Peccoz, P. and Bona, G. (2002) Foetal and Neonatal Thyroid Disorders. Minerva Pediatrica, 54, 383-400.

[9] Zimmerman, D. (1999) Fetal and Neonatal Hyperthyroidism. Thyroid, 9, 727-733. http://dx.doi.org/10.1089/thy.1999.9.727

[10] Daneman, D. and Howard, N.J. (1980) Neonatal Thyrotoxicosis: Intellectual Impairment and Craniosynostosis in Later Years. Journal of Pediatrics, 97, 257-259. http://dx.doi.org/10.1016/S0022-3476(80)80487-2

[11] Zakarija, M., McKenzie, J.M. and Hoffman, W.H. (1986) Prediction and Therapy of Intrauterine and Late-Onset Neonatal Hyperthyroidism. The Journal of Clinical Endocrinology \& Metabolism, 62, 368-71. http://dx.doi.org/10.1210/jcem-62-2-368

[12] Hung, W. and Sarlis, N. (2004) Autoimmune and Non-Autoimmune Hyperthyroidism in Pediatric Patients. Pediatric Endocrinology Reviews, 2, 21-38.

[13] Fong, T.L., McHutchison, J.G. and Reynolds, T.B. (1992) Hyperthyroidism and Hepatic Dysfunction. A Case Series Analysis. Journal of Clinical Gastroenterology, 14, 240-244. http://dx.doi.org/10.1097/00004836-199204000-00010

[14] Skelton, M. (1955) Congenital Thyrotoxicosis, Hepatosplenomegaly and Jaundice in Two Infants of Exophthalmic Mothers. Archives of Disease in Childhood, 30, 460-464. http://dx.doi.org/10.1136/adc.30.153.460

[15] Farber, S. and Craig, J. (1959) Clinical Pathological Conference: The Children's Medical Center Boston, Mass. Journal of Pediatrics, 54, 829-837. http://dx.doi.org/10.1016/S0022-3476(59)80154-2

[16] Hollinsworth, D. and Mabry, C.C. (1976) Congenital Graves Disease. Four Familial Cases with Long-Term Follow-Up and Perspective. American Journal of Diseases of Children, 130, 148-155. 
http://dx.doi.org/10.1001/archpedi.1976.02120030038008

[17] Neal, P.R., Jansen, R.D., Lemons, J.A., Mirkin, L.D. and Schreiner, R.L. (1985) Unusual Manifestation of Neonatal Hyperthyroidism. American Journal of Perinatology, 2, 231-235. http://dx.doi.org/10.1055/s-2007-999957

[18] Cove, D. and Johnston, P. (1985) Fetal Hyperthroidim: Experience of Treatment in Four Siblings. The Lancet, 1, 430432. http://dx.doi.org/10.1016/S0140-6736(85)91148-1

[19] Singer, J. (1977) Neonatal Thyrotoxicosis. Journal of Pediatrics, 91, 749-751. http://dx.doi.org/10.1016/S0022-3476(77)81028-7

[20] Polak, M. (1998) Hyperthyroidism in Early Infancy: Pathogenesis, Clinical Features and Diagnosis with a Focus on Neonatal Hyperthyroidism. Thyroid, 12, 1171-1177. http://dx.doi.org/10.1089/thy.1998.8.1171

[21] Page, D.V., Brady, K., Mitchell, J., Pehrson, J. and Wade, G. (1988) The Pathology of Intrauterine Thyrotoxicosis: Two Case reports. Obstetrics \& Gynecology, 72, 479-481.

[22] Beroukhim, R.S., Moon, T.D. and Felner, E.I. (2003) Neonatal Thyrotoxicosis and Conjugated Hyperbilirubinemia. Journal of Maternal-Fetal and Neonatal Medicine, 13, 426-428. http://dx.doi.org/10.1080/jmf.13.6.426.428

[23] Dryden, C., Simpson, J.H., Hunter, L.E. and Jackson, L. (2007) An Unusual Cause of Neonatal Coagulopathy and Liver Disease. Journal of Perinatology, 27, 320-322. http://dx.doi.org/10.1038/sj.jp.7211687

[24] Loomba-Albrecht, L.A., Bremer, A.A., Wong, A. and Philipps, A.F. (2012) Neonatal Cholestasis Caused by Hyperthyroidism. Journal of Pediatric Gastroenterology and Nutrition, 54, 433-434. http://dx.doi.org/10.1097/MPG.0b013e318228f9a8

[25] Karpen, S.J. (2002) Update on the Etiologies and Management of Neonatal Cholestasis. Clinics in Perinatology, 29,159-180. http://dx.doi.org/10.1016/S0095-5108(03)00069-1

[26] Venigalla, S. and Gourley, G.R. (2004) Neonatal Cholestasis. Seminars in Perinatology, 28, 348-355. http://dx.doi.org/10.1053/j.semperi.2004.09.008

[27] Moyer, V., Freese, D.K., Whitington, P.F., Olson, A.D., Brewer, F., Colletti, R.B., et al. (2004) North American Society for Pediatric Gastroenterology, Hepatology and Nutrition.Guideline for the Evaluation of Cholestatic Jaundice in infants: Recommendations of the North American Society for Pediatric Gastroenterology, Hepatology and Nutrition. Journal of Pediatric Gastroenterology and Nutrition, 39, 115-128. http://dx.doi.org/10.1097/00005176-200408000-00001

[28] Myers, J.D., Brannon, E.S. and Holland, B.C. (1950) Correlative Study of the Cardiac Output and the Hepatic Circulation in Hyperthyroidism. Journal of Clinical Investigation, 29, 1069-1077. http://dx.doi.org/10.1172/JCI102338

[29] Yao, J.D., Gross Jr., J.B., Ludwig, J. and Purnell, D.C. (1989) Cholestatic Jaundice and Hyperthyroidism. American Journal of Medicine, 86, 619-620. http://dx.doi.org/10.1016/0002-9343(89)90398-7

[30] Hayashida, C.Y., Duarte, A.J.S., Sato, A.E. and E Yamashiro-Kanashiro.H. (1990) Neonatal Hepatitis and Lymphocyte Sensitization by Placental Transfer of Prpylthiouracil. Journal of Endocrinological Investigation, 13, 937-941. http://dx.doi.org/10.1007/BF03349663

[31] Deidiker, R. and de Mello, D.E. (1996) Propythiouracil-Induced Fulminant Hepatitis: Case Report Review of the Literature. Pediatric Pathology \& Laboratory Medicine, 16, 845-852. http://dx.doi.org/10.3109/15513819609169310

[32] Foley, T. (1991) Maternally Transferred Thyroid Disease in the Infant: Recognition and Treatment. Advances in Perinatal Thyroidology, 299, 209-226. http://dx.doi.org/10.1007/978-1-4684-5973-9_12 